\title{
The Effectiveness Analysis of Village Donation Allocation Program in Percut Sei Tuan District Deli Serdang Regency
}

\author{
Ami Dilham \\ Management Department \\ Faculty of Economic \\ University of Sumatra Utara \\ Medan, Indonesia \\ *Corresponding Author: amidilham2017@yahoo.com
}

\author{
Aisyah \\ Management Department \\ Faculty of Economic \\ University of Sumatra Utara \\ Medan, Indonesia
}

\begin{abstract}
The purpose of this research is to describe effectiveness of the Village Donation Allocation Program that has been implemented by Deli Serdang Government In Percut Sei Tuan District. The type of this research is descriptive by using qualitative approaching. The effectiveness analyze of Village Donation Allocation Program which contains of two stated that community empowerment builds from the individual to the group to a wider collective and embodies the intention to bring about social and political change in the favor of the 'community' that embarked on the process. In prosperity indicators, the first accuracy of implementation infrastructure and the second is community empowerment. According to the result of research done by using interview, observation and documentation, the researchers can conclude that effectiveness from the village funds in infrastructure such as pavin block, drainage ditch arrangements as well as the context of community empowerment such as making pavin block: $60 \%$, livestock: $30 \%$ and Refill drinking water: $10 \%$.
\end{abstract}

Keywords: village; donation; infrastructure; empowerment

\section{INTRODUCTION}

Villages have a very important role in supporting the success of the National Administration widely. The village is at the forefront of achieving all the affairs and programs of the Government. This is also in line with the composition of the Indonesian population according to the last census in 2000 that around $60 \%$ or the majority of Indonesians currently reside in rural settlements. So it becomes very logical if rural development becomes a top priority for the success of national development.

The village of Percut Sei Tuan District received village fund from the Central Government 2,565,516,000 rupiahs and became the largest recipient village in Deli Serdang Regency while Batu Mbelin Village Namorambe District 548.091.000 Rupiahs. With funds received by 380 villages in Deli Serdang, many programs and activities that can be implemented by the Village Government. Deli Serdang district secretary Asrin Naim at the opening ceremony of socialization of village funding assistance on Tuesday, $26^{\text {th }}$ May 2015 in the hall of High school health Medistra in Deli Serdang Regency. The socialization was presented by Director General of Financing
Management of the Ministry of Finance of RI Dr. Robert Pakpahan accompanied by Member of Commission XI of the House of Representatives of Indonesia, Dr. Ir Nurdin Tampubolon. Each village will get transfer funds from three sources, namely, village funds sourced from the state budget amounting to $105,940,761,000$ rupiahs. This is part of the balance fund or the allocation of village funds amounting to $131,985,865,429$ rupiahs and part of the local taxes and user charges amounting to $30,527,190,533$ rupiahs [1].

For activities that have been carried out in 2016 are the management skills training of village owned Enterprises, data collection and business development of savings and loan economic village, socialization of village owned enterprise management technical guidelines, village market development, village market development, socialization/ guidance on legal regulation analysis related to rural development and rural area [2].

The synergy of planning in the implementation of local authority of the village scale as well as the village apparatus need to prepare a plan involving all components of the village community. A good planning process gives the implementation of a good program and in turn is an important process to achieve the desired results, village planning is important which the village administration must do. Village development planning is a manifestation of the vision of the mission, the elected village head set forth in the development plan of the grant term by the giver and the recipient of the service. Therefore, it is expected that the village apparatus, especially the village head, is more likely to position the village fund allocation as a stimulant for the first is community empowerment planning. It's made both the physical development and the short term or small contribution of infrastructure implementation then it's also important for second is community empowerment.

In the context of infrastructure, different countries have put in place a fundamental and costly study as well as good management concepts that are managed with good project officers. This is the best base line to create synergy in public policy. [3] good project conception and definition, proper cost 
and budget management, adequate stakeholder management, and the appointment of a competent project manager would go a long way in addressing the problems associated with delivery of public sector funded infrastructural projects in Nigeria.

Speaking of infrastructure, it can be attributed to several things. [4] The main contents of the research include a review of logistics development, the characters of various transport operations in logistics activities, the applications of logistics in various fields, city logistics, future direction in logistics development, and its cooperation with transport systems. To sum up, logistics and transportation have some relevance. (1) Logistics system has a more and more important position in our society activities. (2) Transportation and logistics systems have interdependent relationships that logistics management needs transportation to perform its activities and meanwhile, a successful logistics system could help to improve traffic environment and transportation development. (3) Since transportation contributes the highest cost among the related elements in logistics systems, the improvement of transport efficiency could change the overall performance of a logistics system. (4) Transportation plays an important role in logistics system and its activities appear in various sections of logistics processes. Without the linking of transportation, a powerful logistics strategy cannot bring its capacity into full play.

In terms of community activities, can be linked to the activities of the population, especially in the community empowerment, transportation linked to environmental conditions that can be directed to produce results from the creation of society to be more quickly achieved in the target market. In the case of empowerment, the power of the development community actors who cooperatively create synergy and responsive to the problems that occur for the common welfare.

The community empowerment model through cooperative for the villages most severely affected by eruption of Merapi has been done through an integrated strategy of empowerment ranging from the stage of disseminating conscience on the importance of cooperative to an effort of building synergy with other local development actors. In addition, capacity building, cooperative board establishment and obtaining legal status were held in between. Dissemination was intended to stimulate the sense of urgency about cooperative and cultivate understanding that cooperatives require participation of all parties simultaneously for their success [5].

Empowerment, in the concept of work, can psychologically create power in building the village and developing stakeholders within it. [6] Incorporating psychological empowerment into frameworks for the evaluation of community development programs makes power a more central consideration. It can also provide a proximal outcome variable that can be useful for understanding change processes as they unfold, and demonstrating incremental or intermediary gains to stakeholders.
Based on this, the researcher wanted to know what it is to be the implementation in terms of implementation infrastructure and community empowerment to the village donation allocation program in Percut Sei Tuan district Deli Serdang regency.

With globalization, expansion of international trade volume has made essential for countries to improve their logistic capacity. As developments which are in logistic sector make ease production, distribution, and marketing, investments of countries in this field has provided a significant competitive advantage related global trade. An accurate and effective planning of logistics activities is an important way to get both cost and efficiency advantages for countries. Logistics has currently become essential element of trade by taking an active role in this development. Accordingly, developments in logistics sector have a considerable part providing the advantages in terms of growth and development [7].

Community empowerment approaches have been proven to be powerful tools for solving local health problems. However, the methods for measuring empowerment in the community remain unclear and open to dispute. This study aims to describe how a context-specific community empowerment measurement tool was developed and changes made to three health promotion programs in Rapla, Estonia [8].

Promotion practice this process can be best considered as a continuum representing progressively more organized and broadly-based forms of social and collective action, and it is this which is discussed next [9].

Research on communication in CSR has been done with a variety of viewpoints. Those studies reviewed and analized one or more aspects of the communication. Finally, the purpose of this study is to analyze the communication model of CSR program for the empowerment of local communities [10].

Community led initiative in which the community undertake its own appraisal and analysis of open defecation situation and resolve to stop it. It also targets the whole community and spreads naturally. Participants also witnessed community led total sanitation is an approach that facilitates a process of community empowerment [11].

An asset management model to be applied in the civil infrastructure sector. We considered activities at three levels strategic, tactical and operational - in this model to manage assets. In addition, the activities at all levels are developed based on the principle of the Deming cycle. This model was confirmed by a number of experts in several Dutch organizations, where we did the interviews. Necessary also to the construction of facilities and supporting infrastructure and technology development cultivation and livestock production, and the latter, in order to make the forestry sub-sector as the 
basis of economic sectors and sub-sectors, to export it has a significant impact on economic growth in South Sulawesi Province, seen the need to increase the investments in this subsector. Traditional management needs to be directed into a more professional management and modern, so as to increase market share in the commodity sub-sector [12].

Self reinforcing mechanisms and network externalities have an important role in the development of information technology infrastructure. In infrastructure investments and fixed costs are often significant and therefore it is expected that the infrastructure will serve for years ahead. In this situation it is clear that earlier decisions have an impact that will affect the development for years, creating both lock-in and path-dependence in the information technology infrastructure management [13].

The difference between current state and desire state in knowledge management implementation is very noticeable and it seems as if according to the importance of this matter, such organizations with low level of knowledge management implementation need planning and emphasizing on effective factors based on priority. According to the result of this research it is suggested that: Training and development of effective infrastructure in knowledge transfer, Knowledgeable human resource development as the key element in knowledge management system, Design and deployment of required information system as knowledge management system infrastructure, Promotion of participatory for knowledge sharing and quality development to be considered [14].

The ability of company to respond to customer concerns is impacted by the Information Technology Infrastructure (ITI). By creating relevant, timely and flexible ITI, companies are more likely to sense customer's interests so that they can respond in timely manner. Finally, our study argues that for achievement business advantages, a company should be capable of manages ITI. Summarize the ideas; we hope that the importance of an ITI would be better understood [15].

\section{RESEARCH METHODOLOGY}

In order to achieve the goals of the study, the conclusions have been supported by the results of qualitative research conducted in 2016 among the community in Percut Sei Tuan District Deli Serdang Regency. The following research problems were formulated. Based on indicators: first accuracy of implementation infrastructure and the second is community empowerment.

The study involved a sample of random representatives of communities the groups of actors representative involved in 20 Villages concerning various issues, both infrastructure and community empowerment using purposive sampling technique. There was an individual in-depth interview (IDI) conducted with each participant of the study. Another source of empirical material was a focus group interview (FGI) conducted among actors.

\section{RESULTS AND DISCUSSION}

\section{A. Qualitative analysis of facilities and infrastructure}

Frequency of Facilities and Infrastructure focuses on the allocation of village funds in 2016, is in a good zone, although much still needs to be improved in order to reach the desired stage of public facilities. Making roads with pavin block, the construction of religious facilities with the results of community empowerment has been done well. For the drainage ditch, the drainage has not run maximally due to limited funds for allocation of funds and will be resumed in subsequent disbursement. This is the rationale for the next policy determination.

Problem Factors of facilities and infrastructure is a culvert that is not feasible in some villages and needs improvement because it often causes flooding if rain falls. This is a fundamental issue and will be a further allocation in 2018 with a work plan of 2017. It is now running in several places in Percut Sei Tuan District and will be implemented in other areas. Society and government together work together to make this happen.

In general, the role of the government through village funds for infrastructure facilities and infrastructure for village funds is prioritized to the infrastructure sector and further research is needed to be able to use wisely to avoid problems in the legal field. Legal issues are a matter of concern so that the precautionary principle in the use of these funds becomes a reference policy for the government and society. This is one part in running the principle of fair and equitable policy.

The level of efficiency and effectiveness in the use of the village funds from the infrastructure aspects has been managed by $75 \%$ which is used for infrastructure gradually used in accordance with its effectiveness. $25 \%$ is used for education, health and community empowerment concerning the fundamental aspects of public policy. It still needs to be increased in the use of funds in the next fiscal year and is part of a policy that takes care of the principle of prudence.

The results from the village funding oversight for infrastructure are intensified and the process of monitoring is done by the inspectorate and village community actively. Until now the village of Percut Sei Tuan District get qualified management results because managed efficiently and effectively and felt the public there is increasing public access. Improving the quality of this development is a manifestation of the active role of society and government.

\section{B. Qualitative analysis of community empowerment}

Frequency of Community Empowerment has been effective since 2016 with 3 developing business that is making pavin block: $60 \%$, livestock: $30 \%$ and refill drinking water: 
$10 \%$ which is the main factor which has done coaching efficiently and effectively with developed inspiration Through training carried out by the village and has become a continuously developed program.

The problem of the empowerment of the community is the lack of access to technology because it is still focused on the conventional concept, the marketing is still inaccessible from the domestic side effectively and less follow the times as well as the income level of the family is still small. From this problem is something that is found in some areas in the Percut Sei Tuan District.

The role of the government through the village funds for empowerment has been excellent and has developed village funds to be quicker to the productive sector and to the right target. The problem in allocating village funds is the lack of innovation because there is no freedom of expression because it is vulnerable to legal issues, where the funds used must be channeled properly and if not allocated properly, it will be a finding that will be problematic with the law. This is required to carry out the maximum role of all element communities and governments.

The level of efficiency and effectiveness in the use of empowerment aspects work well according to the expectations of all parties and the need for an innovation that is the hope of a growing business. Some innovations that need to be generated is mechanization technology that is processing waste into animal feed. With this utilization, able to produce an improvement of business results and can develop a new business results which is the development of the concept of community empowerment. The trials have begun in 2017 and are planned to collaborate with the mechanization team of academics to realize the mechanization goes well.

Results from village funding oversight for empowerment Planned efficiently and effectively. This is evident from the development of other more creative findings so that village funds can be absorbed based on existing potential and develop something new to produce an innovation of citizens with global competitiveness. More segmented training, especially from the marketing field, is a solution to effective outcomes in the development of village funds in the community empowerment sector. The number of partners that can be a partnership, is an alternative in improving the concept of community empowerment in the Percut Sei Tuan District.

\section{Discussion}

1. The Effectiveness of village funds in infrastructure arrangements

As the research [3] that a competent project manager would go a long way in addressing the problems associated with delivery of public sector funded infrastructure projects. From Percut Sei Tuan District, making roads with pavin block had been done well. The drainage ditch also had been done maximally used as a step for the comfort of the community to conduct business activities and can support the concept of community empowerment in Percut Sei Tuan District.

Logistics system has a more and more important position in our society activities as the investigation [4]. Government action In Percut Sei Tuan District through village funds for infrastructure facilities and infrastructure from village funds must avoid the problems in the legal field. Legal issues are a matter of concern so that the precautionary principle in the use of these funds becomes a reference policy for the government and society. In the long term, developments in logistics sector have a considerable advantage in terms of growth and development of Percut Sei Tuan District which is still concerned with the concept of prudence in using village funds like the inspiration from the investigation [5].

An asset management model to be applied in the civil infrastructure sector. The level of efficiency and effectiveness in the use of village funds can be managed by $75 \%$ which is used for infrastructure gradually used in accordance with its effectiveness. $25 \%$ is used for education, health and community empowerment concerning the fundamental aspects of public policy. It still needs to be increased in the use of funds in the next fiscal year and is the part of a policy that takes care of the principle of prudence. The amount of funds allocated to infrastructure is part of an asset management model to be implemented in the civil infrastructure sector. The considered activities at three levels - strategic, tactical and operational - in this model to manage assets. The continuity of the activity is a step in improving the quality of the infrastructure building as the investigation [6].

In this situation it is clear that earlier decisions have an impact in the information technology infrastructure management can be seen from the village funding oversight for infrastructure are intensified and the process of monitoring is done By the inspectorate and village community actively. Training and development of effective infrastructure in knowledge transfer, Knowledgeable human resource development as the key element in knowledge management system. This should be developed so as to obtain effective results in the management of village funds and can see references from other villages as the investigation [7].

It is also necessary for the construction of facilities and supporting infrastructure and technology development cultivation and production as the investigation [7]. Until now Desa Percut Sei Tuan District gets qualified management results by managed efficiently and in fact the public that there is increasing public access. Improving the quality of this development is a manifestation of the active role of society and government. The tangible results of this infrastructure, will be seen by the increased investment created from the community empowerment sector. 
2. The Effectiveness of village funds in the context of community empowerment

It is expected that the village apparatus, especially the village head, is more likely to position the village fund allocation as a stimulant for the first is community empowerment planning. From 2016, the results obtained are making pavin block: $60 \%$, livestock: $30 \%$ and refilling the drinking water: $10 \%$ which is the main factor for coaching efficiently and effectively with developed inspiration. From the excavated potential, the management skills Training of village owned Enterprises, data collection and business development of savings and to be powerful tools for solving local health problems as the investigation [8].

Economic village, socialization of the village owned enterprise management technical guidelines, village market development as the investigation [9]. The problem of the empowerment of the community is the lack of access to technology because it is still focused on the conventional concept, the marketing is still inaccessible from the domestic side so that it is needed to be thought about the community empowerment model through cooperative for the villages as it happens most severely affected by eruption of Gunung Merapi has been done through an integrated strategy of empowerment ranging from the stage of disseminating conscience as the research [10].

Incorporating psychological empowerment into frameworks for the evaluation of community development programs makes power a more central consideration as the inspiration [11]. The problem in allocating village funds is the lack of innovation because it is vulnerable to legal issues, where the funds should be channeled properly and if not allocated properly, it will be a problem that will be problematic with the law. Generally, the Percut Sei Tuan District government had done the effectiveness of managing village funds properly and creating community empowerment approaches have been proven to be powerful tools for solving local prosperity problems.

Promotion this practice can be considered as a continuum representing progressively more organized and broadly-based e innovations that need to be generated is mechanization technology. By this utilization, it is able to produce an improvement of business results which is the development of the concept of community empowerment. The trials have begun in 2017 and are planned to collaborate with the mechanization team of academics to realize the mechanization goes well. Research on communication in Village Donation has been done with a variety of viewpoints. Those studies reviewed and analyzed one or more aspects of the communication as the research [12]

Participants also witnessed a community empowerment process. This is evident from the development of more creative findings so that village funds can be absorbed based on existing potential and develop something new to produce an innovation of citizens with global competitiveness. Finally, for a business collaboration needed the development of ITI [13], the information system as knowledge management system [14] and the ability of company to respond to customer [15].

\section{CONCLUSIONS}

In analyzing the village fund Percut Sei Tuan District divided into 2 parts of funding that is:

A. The Effectiveness of village funds in infrastructure arrangements which can be exposed:

1. From infrastructure side, Percut Sei Tuan District had made the action such as making roads with pavin block has been done well and For the drainage ditch has been done maximally used as a step for the comfort of the community to conduct business activities and can support the concept of community empowerment Percut Sei Tuan District.

2. Government action In Percut Sei Tuan District through village funds for infrastructure facilities and infrastructure for village funds must avoid the problems in the legal field. Legal issues are a matter of concern so that the precautionary principle in the use of these funds becomes a reference policy for the government and society.

3. The level of efficiency and effectiveness in the use of village funds can be managed by $75 \%$ which is used for infrastructure gradually used in accordance with its effectiveness. 25\% is used for education, prosperity and community empowerment concerning the fundamental aspects of public policy.

4. In the information technology infrastructure management can be seen from the village funding oversight for infrastructure are intensified and the process of monitoring is done By the inspectorate and village community actively and it needs the training and development of effective infrastructure in knowledge transfer, Knowledgeable human resource development.

5. Until now the village of Percut Sei Tuan District get qualified management results by managed efficiently and in fact the public that there is increasing public access. Improving the quality of this development is a manifestation of the active role of society and government.

B. The Effectiveness of village funds in the context of community empowerment which can be exposed :

1. From the year 2016, the results obtained are making pavin block: $60 \%$, livestock: $30 \%$ and Refill drinking water: $10 \%$ which is the main factor which has done coaching efficiently and effectively with developed inspiration. 
2. The problem of the empowerment of the community is the lack of access to technology because it is still focused on the conventional concept, the marketing is still inaccessible from the domestic side so that it is needed to be thought about the community empowerment model through cooperative for the villages.

3. In general, the Desa Percut Sei Tuan District government has done the effectiveness of managing village funds properly and creating community empowerment approaches have been proven to be powerful tools for solving local prosperity problems.

4. By utilization was able to produce an improvement of business results which is the development of the concept of community empowerment. The trials have begun in 2017 and are planned to collaborate with the mechanization team of academics to realize the mechanization goes well.

5. Finally, our study argues that for a business collaboration, an effective collaboration from government, private and academia goes to business innovation and creates efficient effectiveness of village funds and avoids administrative failures that result in to legal issues.

\section{ACKNOWLEDGEMENTS}

The author's research is funded by The Grant Of Research Institute of University of Sumatra Utara, Fiscal Year 2017 Number: 5338 / UN5.1.R / PPM / 2017, Date 22 ${ }^{\text {nd }}$ May 2017.

\section{REFERENCE}

[1] Http://hariansib.co.id (2015, 05 26). Saentis-Percut-Seituan-PenerimaDana-Desa-Terbesar-di-Deliserdang. Retrieved 07 28, 2017, from http://hariansib.co/view/Medan-Sekitarnya/60462/Saentis-PercutSeituan-Penerima-Dana-Desa-Terbesar-di-Deliserdang.html: http://hariansib.co/view/Medan-Sekitarnya/60462/Saentis-PercutSeituan-Penerima-Dana-Desa-Terbesar-di-Deliserdang.html

[2] Http://bpm.deliserdangkab.go.id.(2016,1101). http://bpm.deliserdangkab.go.id/content/index/4/id_kegiatan?id=3. Retrieved 07 28, 2017, from http://bpm.deliserdangkab.go.id: http://bpm.deliserdangkab.go.id/content/index/4/id_kegiatan?id=3

[3] A. Diugwu, I., Musa, M and L. Baba, D. (2015). Towards Effective Infrastructure Development in Nigeria: Theoretical Considerations from a Project Management Perspective. American Journal of Industrial and Business Management, pp.172-180.

[4] Yu Tseng, Y., A P Taylor, M and Long Yue, W. (2005). The Role Of Transportation In Logistics Chain. Proceedings Of The Eastern Asia Society for Transportation Studies, Vol. 5, pp.1657 - 1672.

[5] Masrukin, Sabiq, A., Sugito, T and Suswan, B. (2016). Community Empowerment Model through Cooperative for the Villages Most Severely Affected By Eruption of Merapi. International Journal of Social Science and Humanity, Vol. 6, pp.57-60.

[6] Christens, B. D. (2012 ). Targeting empowerment in community development: a community psychology approach to enhancing local power and well-being. Community Development Journal Vol 4, pp.538554.
[7] Ramli, A. (2015). Strengthening Agricultural Sector Superior Commodities -Based Against the Economic Growth in South Sulawesi, Indonesia. International Journal of Advanced Research Vol 3, pp.753760 .

[8] Kasmel, A., Andersen, P. T. (2011). Measurement of Community Empowerment in Three Community Programs in Rapla (Estonia). International Journal of Environmental Research and Public Health, pp.799-817.

[9] Munodawafa, D., Aggrawal, S and Chatterjee, M., J. S, T., \& R. K, S. (2009). Women's empowerment to address social and economic determinants of health: A Self-Employed Women's Association (SEWA) experience. 7th Global Conferenceon Health Promotion, "Promoting Health and Development: Closing the Implementation Gap" .Nairobi,Kenya,:Llandud no http://www.sxc.hu/photo/817316, pp.13-20.

[10] Nugroho, D. R., Vitayala S. Hubies, A., Saleh, A and Wahyu Priatna, B. (2016). Communication Model Of Corporate Social Responsibility Program For Community Empowerment. International Journal Of Research In Social Sciences, Vol. 6, pp.1-10.

[11] Gebresilase, Y. (2010). Community Led Total Sanitationand Empowerment: The Case Ofdorze Hyzo Community, Snnpregion Of Ethiopia (Aphenomenological Study). International Journal of Sustainable Development Vol 1, pp.99-107.

[12] Van Houten, T., L. Zhang, L. (2010). Managing Assets in The Infrastructure Sector. International Journal of Engineering Business Management, Vol. 2, pp.55-60.

[13] Sirkemaa, S. (2015). Towards Information Technology Infrastructure Management. Journal Of Emerging Trends In Computing And Information Sciences Vol. 6, pp.614-621.

[14] Ebrahim Razaghi, M. (2014). Evaluating the Implementation of Knowledge Management in Offices of Youth and Sport in Iran: Fuzzy logic method. International Journal of Sport Management, Recreation \& Tourism Vol 16, pp.56-68,.

[15] Gheysari, H., Rasli, A., Roghanian, P and Jebur, H. (2012). The Role of Information Technology Infrastructure Capability (ITIC) in Management. IJFPSS, Vol 2, pp.36-40. 